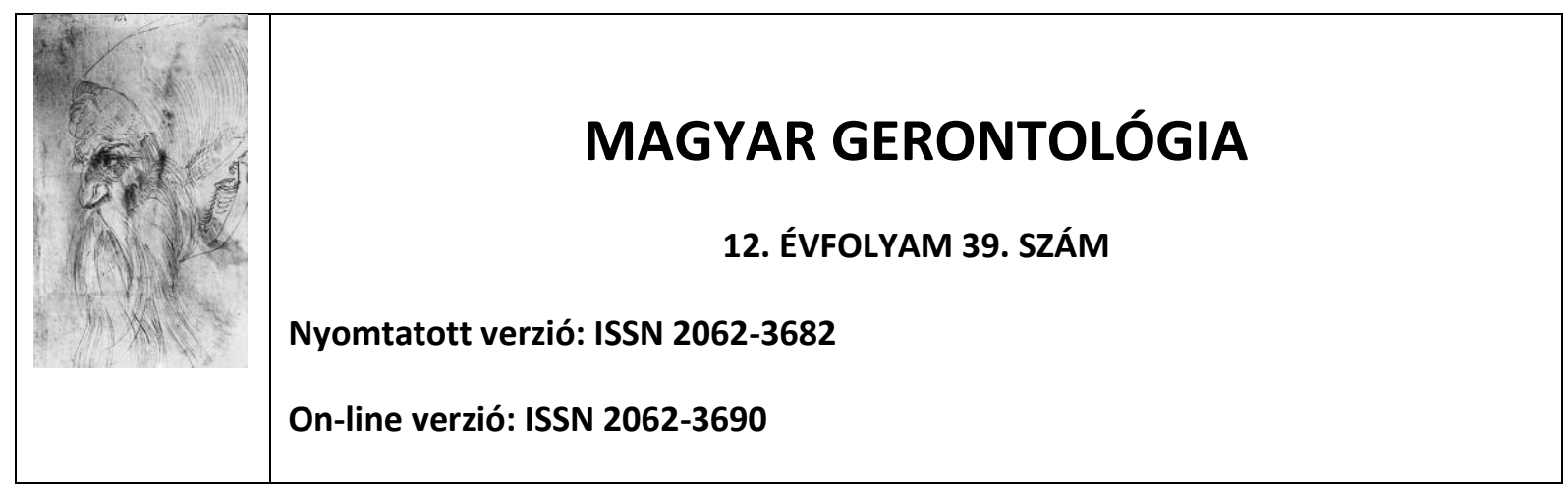

\title{
AKTÍV, ALKOTÓ IDŐSÖDÉS II. - ÁRAMLAT-ÉLMÉNY
}

\author{
Ferwagner Anna \\ ferwagner.anna@gmail.com \\ Pék Győző \\ Debreceni Egyetem, Pszichológiai Intézet \\ 4032 Debrecen, Egyetem tér 1. \\ viktorbaker55@gmail.com
}

\section{ÖSSZEFOGLALÁS}

Háttér és célkitüzések: Kutatásunkban azt vizsgáltuk, hogy az idős emberek milyen flow- és antiflow-élményt élnek át különböző élethelyzetekben (egyedüllét, családdal és barátokkal töltött idő, háztartási munkavégzés, szabadidős vagy alkotó tevékenység). Módszer: Vizsgálatunkban az Oláh-féle flow- és antiflow-élményt (szorongás, unalom, apátia) vizsgáló kérdőívet alkalmaztuk. Eredmények és következtetések: Alkotó tevékenység és egyéb szabadidős tevékenységek végzése során összességében nagyobb flow és kisebb antiflowélmény élhető át, mint háztartási munkák végzése közben. A családi körben átélt flow az időseknél magasabb, mint a baráti társaságban átélt. Az alkotó tevékenységgel foglalkozók magasabb flow- és alacsonyabb antiflow-élményröl számoltak be egyedüllét során, mint az egyéb szabadidős tevékenységgel foglalkozó kontrollcsoport.

Kulcsszavak: flow, alkotás, időskor, aktív idősödés 


\title{
ACTIVE, CREATIVE AGING II. - FLOW
}

\begin{abstract}
SUMMARY
Background and aims: In our research, we examined the flow and antiflow experience that older people experience in different life situations (loneliness, time with family and friends, domestic work, leisure or creative activity). Methods: In our study, we used a questionnaire examining flow and antiflow experience (anxiety, boredom, apathy) by Oláh A. Results an discussion: Overall, creative activity and other leisure activities provide greater flow and less antiflow experience than doing housework. The flow experienced in the family circle is higher in the elderly than in the group of friends. Those engaged in creative activity reported higher flow and lower antiflow experience during loneliness than the control group engaged in other leisure activities.
\end{abstract}

Keywords: flow, creating, elderly, active ageing

\section{BEVEZETÉS}

„Élni annyit jelent, mint cselekvések, érzések és gondolatok segítségével megtapasztalni a világot. (...) Ahogy múlnak az évek, tapasztalataink egyre markánsabban nyomják rá bélyegüket életünk minőségére, és egyre inkább az lesz leglényegesebb döntésünk, hogy mibe fektessük időnket, hogyan gazdálkodjunk vele. ”(Csíkszentmihályi, 1998, 15. old.)

Csíkszentmihályi (1997; 1998; 2008) szerint saját elhatározásunkon múlik, hogyan éljük le életünket, magunknak kell rájönni, hogyan kell helyesen élni, olyan életet megvalósítani, melyben kifejezésre tud jutni egyediségünk, önvalónk és környezetünkkel is harmóniában tudunk élni. Mindezt pedig a hétköznapok valóságába ágyazva kell elképzelni.

\section{Aktív idösödés}

Napjaik kb. kétharmadát töltjük aktívan (a többit alvással), s ennek főbb paraméterei történelmi koronként és kultúránként nagyon hasonlóan alakulnak, az ember nemének, korának és szociális helyzetének megfelelő egyéni eltérésekkel. Az aktívan töltött időben a napi tevékenységek három főbb tevékenységcsoportba sorolhatók. A produktív tevékenységek létfenntartásunk és kényelmünk biztosításához szükséges erőforrások megszerzéséért végzett tevékenységek (pl. munka, tanulás), amelyekkel időnk kb. negyedét-felét töltjük. A karbantartó 
tevékenységek testünk formában tartását és a hozzánk tartozó dolgok állagmegőrzését szolgálják (pl. házimunka, étkezés, közlekedés, testápolás, öltözködés), amelyekkel időnk kb. negyedét töltjük. A szabadidős tevékenységek a produktív és karbantartó tevékenységek végzését követően fennmaradó időben végzett tevékenységek (pl. pihenés, társas élet, hobbik), amelyekkel szintén időnk kb. negyedét töltjük. Életünk tehát ezen tevékenységekből és a tevékenységek során átélt élményekből áll össze. Csíkszentmihályi (1997; 1998; 2008)

Kapcsolatainkat legtöbbször háromféle kapcsolatrendszerben éljük. A munkatársakkal, iskolatársakkal, idegenekkel való kapcsolat az a nyilvános tér, amelyben egyszerre jelenik meg a másokkal folytatott versengés és együttműködés, ahol lehetőségünk nyílik képességeink kibontakoztatására, ugyanakkor cselekedeteink mások által megítélésre is kerül. A család (szülők, gyerekek, testvérek, házastárs) az a biztonságos közeg, amelyben nagyobb felelősséget vállalnak egymás iránt az emberek. Az egyedüllét a legkevésbé kedvelt állapot, amelyet megélhetünk magányként is, s igyekszünk menekülni belőle vagy megtanulhatunk élni vele, sőt a magány élvezete is tanulható. Csíkszentmihályi (1997; 1998; 2008)

Számos dologtól függ annak megítélése, hogy mennyire érezzük magunkat boldognak, ilyen az egészség, magas önbecsülés, extrovertáltság, istenhit, házasság. Jobb közérzetet biztosít az önként vállalt tevékenységek végzése, ez azonban nem jelenti azt, hogy a kötelező feladatok elvégzése rosszabb közérzetet okozna. Szintén hozzásegíthet a boldogság megéléséhez, ha létünknek értelmet adó célokat tüzünk ki magunk elé. Frankl (1996) szerint azonban nem önmagában a boldogságot kell akarni, hanem a boldogság alapját, hiszen az embert végső soron nem az örömre, hanem az értelemre való törekvés hatja át. A boldogság keresése nem lehet önmagában cél, csakis az értelem keresésének és megtalálásának a kísérője.

Mivel az idősödés során egyre kevesebb időt kell az anyagi javak megszerzésével (produktív tevékenységek végzésével) tölteni, így egyre több idő jut a szabadidős és karbantartó tevékenységek végzésére, továbbá a családdal és barátokkal való időtöltésre. Az időskorba lépve ismét életünk részét képezhetik olyan dolgok, amelyekre életünk korábbi szakaszaiban nem jutott idő (pl. hobbik, kreatív tevékenységek, művészetek). Az élet vége felé közeledve az emberek még inkább megfontolják, mire használják fennmaradó idejüket.

Aktív időskor alatt azt értjük, amikor az emberek az egészségük és fizikai aktivitásuk megőrzésére és fejlesztésére, szociális és mentális jóllétükre törekednek, biztosítják részvételüket a társadalomban, továbbá összeegyeztetik, optimalizálják igényeiket, lehetőségeiket és képességeiket. Az aktív idősödés elősegíti az idősödő és időskorú generáció 
aktív részvételét a szabadidős tevékenységekben, társadalmi- és kulturális életben, az oktatási rendszerben és a munkaerőpiacon egyaránt. (Brettner, 2013)

Az aktív idősödés által lehetőség nyílik a „, sikeres öregedésre” a funkciócsökkenéssel járó ,, szokásos öregedéssel” vagy a funkciózavarral, betegségekkel járó „, leromló öregedéssel” szemben. A „sikeres öregedés” új erőforrások kialakítására képes viselkedésmintázatnak tekinthető, magában hordozza a rugalmasságot, pozitív életszemléletet is, így egyfajta megküzdésnek is tekinthető. (Kerekes, 2013)

A tevékeny élethez nagymértékben járulnak hozzá azon tevékenységek is (pl. sport, tanulás), amelyek belső motivációt, kitartást igényelnek, és végső soron hozzásegítik az embert az áramlat-élmény (flow) átéléséhez. (Delle Fave, 2011) Az alkotás folyamata önkifejezés, lehetőséget teremet a belső tartalmak kivetítésére, a művészekben megjelenő vágyak megvalósítására egy fantáziavilág révén, és szintén hozzásegít az áramlat-élmény átéléséhez. (Csíkszentmihályi, 2014; Halász, 2006)

\section{Áramlat-élmény}

Az áramlatélmény nem definiálható egyértelmủen, számos jellemzője alapján azonban jól körülírható. Célkitüzéseink világosak, egyértelmüek és azonnali visszajelzés van arról, hogy jól végezzük-e tevékenységünket, amely igénybe veszi képességeinket, a tevékenység felett kontrollt érzünk. Figyelmünk aktív, érdeklődö, lekötött és összpontosított, a tudatból kiszorulnak a figyelemelterelő gondolatok, a tudat és a tevékenység egybeolvad. Annyira belefeledkezünk a tevékenységbe, hogy az idő torzulása figyelhető meg közben és úgy érezzük, tevékenységünk szinte automatikusan zajlik. Az ilyen helyzet tanulásra ösztönöz, új kihívások keresésére, egyre magasabb szintü készségek elsajátítására. (Csíkszentmihályi, 1997; 1998; 2008)

„Áramlat akkor lép fel, ha az egyénnek próbára kell tennie képességeit ahhoz, hogy egy feladatot megoldjon. A tökéletes élmény általában törékeny egyensúlyt feltételez az egyén cselekvési képességei és a cselekvés megvalósitási lehetöségei között." (Csíkszentmihályi, 1998, 37. old.) Amennyiben képességeinkhez képest túl magasak a kihívások, szorongás lép fel, míg túl alacsony kihívások esetében unalom vagy apátia. Mind képességeink észlelésekor, mind pedig a kihívások megítélésekor szubjektív megélésünk számít.

Áramlat-élményt bármilyen tevékenység végzése közben át lehet élni. Leginkább a szabadidős tevékenységek (főként sport, játékok és kedvtelések) végzése közben jellemző, azonban a kihívást igénylő produktív tevékenységek (munka) végzése közben is előfordulhat, 
legkevésbé pedig a karbantartó tevékenységek (háztartás) során éljük át. Kapcsolatainkat illetően a barátainkkal töltött idő közben magasabb áramlat-élményt élünk át, mint családi körben, míg legkisebb mértékben egyedüllét alatt éljük át. Egy Németországban végzett felmérés szerint, a megkérdezettek 23\%-a gyakran, 40\%-a néha, 25\%-a alig és 12\%-a soha nem él át áramlat-élményt. (Csíkszentmihályi, 1998, 40. old.)

Az áramlat-élmény vizsgálata leginkább a fiatalabb generációk körében jellemző, a kutatások kiemelt helyszíne az iskola. A vizsgálatok fókusza a különféle tanórákon, valamint a baráti és családi kapcsolatokban átélt áramlat-élmény, szorongás, unalom és apátia érzésének felmérésén van. Szintén kiemelt kutatási terület a tehetséggondozás, a müvészeti tevékenységek során átélt áramlat-élmény vizsgálata. (Csíkszentmihályi, 2010; Janurik, 2007; Janurik és Pethő, 2009; Pinczés és Pikó, 2014). Jelen felmérésünk ezzel szemben az idősebb generációlat célozta meg.

Reynolds és Prior (2006) kvalitatív vizsgálatában rákos megbetegedéssel küzdők félig struktúrált interjúk során számoltak be vizuális müvészi tevékenység végzése közben átélt áramlat-élményükről. Az alkotó tevékenység során átélt áramlat-élmény segítette a rákkal kapcsolatos gondolatok háttérbe szorítását, a rákkal való megküzdést.

Kutatásunkban az idősödő és időskorú emberek által különféle élethelyzetekben, például egyedüllét, családdal vagy barátokkal töltött idő, háztartási munkavégzés vagy szabadidős tevékenység alatt átélt áramlat-élményt, szorongást, unalom és apátia érzést vizsgáltuk. Vizsgálatunkban arra kerestünk választ, hogy a fenti élethelyzetekben eltérő mértékü flow és antiflow élményt élnek-e át azon emberek, akik maradandó alkotás létrehozására irányuló akotó tevékenységgel (pl. képzőművészet, textilművészet, kézművesség) foglalkoznak, szemben azokkal, akik egyéb szabadidős tevékenységekkel (pl. olvasás, torna, színházba járás, stb.).

Kutatásunkban szintén vizsgáltuk az időskori depressziót, az élettel való elégedettséget, az élet értelmességének megítélését és a megküzdést, melynek eredményei egy másik tanulmány keretében kerülnek bemutatásra (Aktív, alkotó idősödés I. - Megküzdés). 


\section{MÓDSZEREK ÉS MINTA}

Vizsgálatunkat 2017 tavaszán végeztük, a kutatás etikai engedélyét a Debreceni Egyetem 2017/46/91. számon adta meg. A vizsgálati személyek idősödő és időskorú személyek voltak, toborzásuk részben informális kapcsolati hálón keresztül, részben alkotómühelyek, klubok (Budapest XI. kerület Újbuda 60+ programsorozatának festőcsoportjai, a Budapesti Müvelődési Központ Alkotó Stúdiói, a Budakeszi Generációk Háza Alkotó Körei, egyéb klubokban vagy önállóan alkotók) megkeresésével történt, nyomtatott önkitöltős kérdőív segítségével. A mintavétel során a nemek közötti egyenletes megoszlás nem volt biztosítható, mivel az alkotómühelyekben, alkotóklubokban müködő alkotó csoportok résztvevői döntő többségben nők. A vizsgálatban 73 fő vett részt, 16 férfi és 57 nő, életkoruk 60-91 év (átlagosan 70 év) volt. A vizsgálat során saját szerkesztésű kérdőivet (alapvető demográfiai adatok és az alkotó vagy egyéb szabadidős tevékenység végzésére irányuló kérdések), továbbá az alábbi standardizált kérdőívet használtuk.

\section{Oláh-féle Flow Kérdöív (Oláh, 2005)}

A kérdőív 22 kérdésből áll, az állításokkal való egyetértést 5 fokozatú Likert-skálán kell jelölni. A teszt alkalmas a különféle élethelyzetekben, tevékenységek végzése közben átélt flow és antiflow mérésére, ennek megfelelően négy alskálára osztható: flow, szorongás, unalom, apátia. A kédések az adott tevékenység végzése kapcsán a személy képességeire és a feladat kényszerjellegére kérdeznek rá. Az egyén kompetenciáihoz viszonyított túlságosan megerőltető feladat szorongást vált ki, míg az érdektelen feladat unalmat és apátiát. Az egyén számára kihívást jelentő, a figyelmét teljes mértékben lekötő feladatok vezetnek áramlat-élményhez. A flow elérését facilitáló temperamentum vonások az újdonságkeresés és a jutalomfüggés, a flow fennmaradását biztosító vonások az önirányítottság, együttműködés és transzcendencia, míg a flow-ban maradással a stabilitás és ártalomkerülés van kapcsolatban.

A teszt eredetileg iskoláskorú gyermekek iskolában, egyedül, családban és baráti körben töltött időben átélt áramlat-élményének felmérésére készült, ugyanakkor alapvetően bármely más élethelyzetre, tevékenységre is alkalmazható (pl. szabadidős tevékenység). Müvészeti és nem müvészeti képzésben résztvevő középiskolai tanulók vizsgálatakor azt találták, hogy alkotó tevékenység és játék közben élnek át kiemelkedően magas flow-t, ennél kisebb a családi körben átélt flow, míg az iskolában és háztartás végzése közben a legkisebb mértékü. (Bagdi és mts., 2014; Oláh, 2005) 
Vizsgálatunkban a következő hipotéziseket fogalmaztuk meg. H1: Az alkotó tevékenység közben átélt áralat-élmény áttevődik más tevékenységek végzésére, így a különféle élethelyzetekben mérhető flow az alkotók esetében magasabb, mint a kontrollcsoportnál. H2: Az alkotó tevékenység időtartama (milyen régóta végzik a vizsgálati személyek), illetve rendszeressége (heti hány órában végzik) összefügg az áramlat-élmény mértékével.

A felvett kérdőívek eredményeit Microsoft Excel és RStudio matematikai-statisztikai programmal elemeztük. Valamennyi folytonos változóra (flow alskálák, alkotó tevékenység végzésének eddigi és heti időtartama) kapott értékek esetében normalitás vizsgálatot végeztünk a Shapiro-Wilk teszttel ( $p>0.05$ esetén a változó normális eloszlású). A normalitásvizsgálat alapján a változók eloszlása az egyes csoportokban vegyesen normális és nem normális eloszlású, ugyanakkor döntő részt nem normális eloszlást mutat $(\mathrm{p}<0.05)$, így a csoportok egységes összehasonlíthatósága érdekében az egyes csoportok összehasonlítására a MannWhitney próbát alkalmaztuk és a medián értékek kerültek megadásra. Az egyes csoportokon belüli összehasonlításokat Friedman-próbával, majd páros Wilcoxon-próbával végeztük el. Annak vizsgálatára, hogy az alkotó tevékenység időtartama (milyen régóta végzik a vizsgálati személyek a tevékenységet), illetve rendszeressége (heti hány órában végzik a tevékenységet) milyen hatással van az áramlat-élményre, Spearman-féle rangkorrelációs vizsgálatot végeztünk.

\section{EREDMÉNYEK}

Az alkotók csoportjába 37 fő, a kontrollcsoportba 36 fő került besorolásra. Az alkotók csoportjába tartozók főként festészettel, grafikával és kézműves alkotó tevékenységgel foglalkoznak rendszeresen, heti 1-20 órában, legalább 1/2 éve. A kontrollcsoportba tartozók 36 \%-a nem jelölt meg olyan szabadidős tevékenységet, mellyel rendszeresen foglalkozna. $64 \%$ uk főként passzív tevékenységeket (olvasás, rejtvényfejtés, írás), testmozgással járó tevékenységeket (torna, kertészkedés), illetve kulturális eseményeken való részvételt (színház, klubok) jelölt meg szabadidős tevékenységként. Heti 2-20 órában, legalább 1/2 éve foglalkoznak ezen tevékenységekkel. 
Az alkotók és a kontrollcsoport különböző helyzetekben átélt áramlat-élményeinek összehasonlítását az 1. ábra mutatja be.

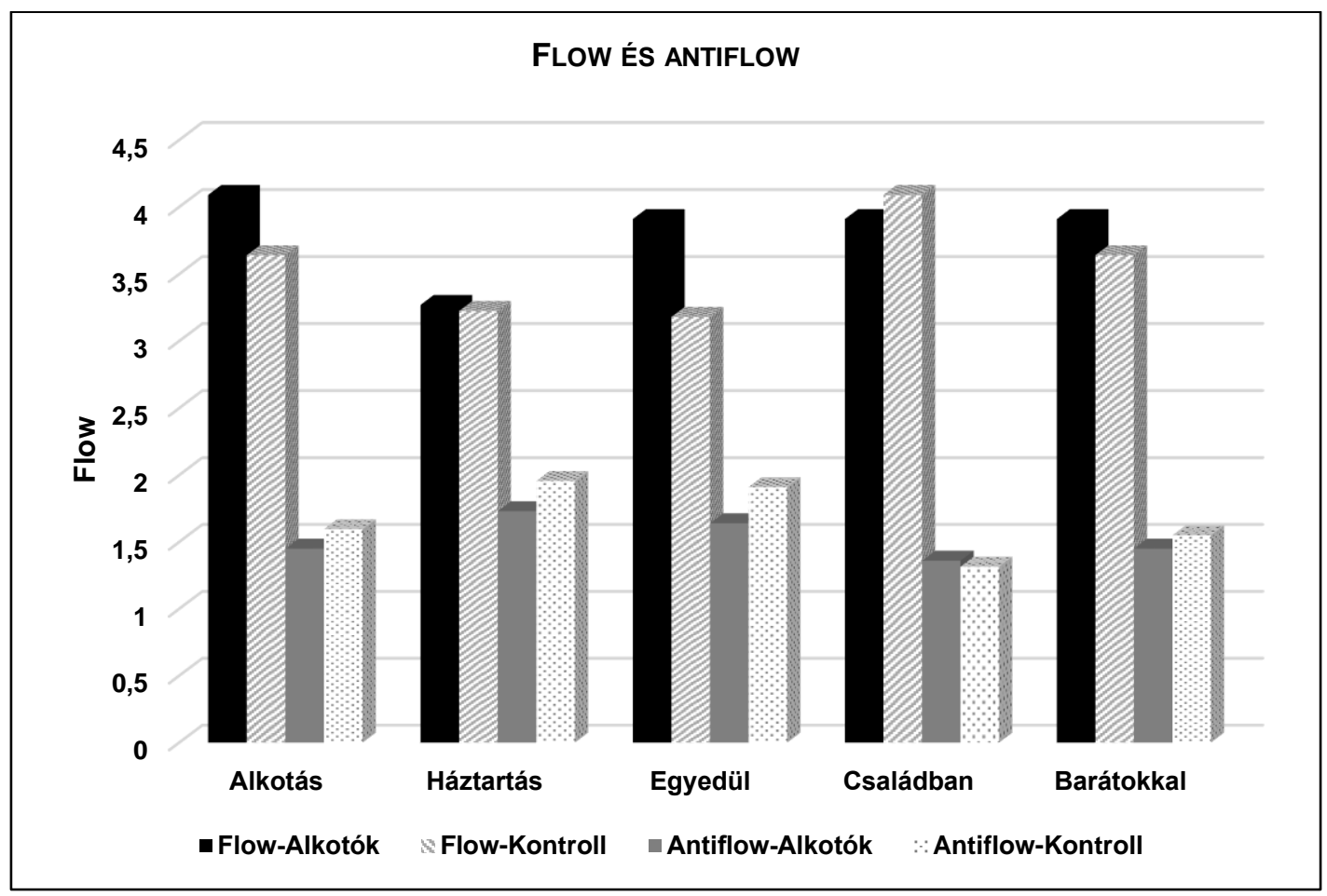

1. ábra: Az alkotók és a kontrollcsoport különbözö helyzetekben átélt áramlat-élményei

Az alkotók és a kontrollcsoport eredményeit összehasonlítva megállapítható, hogy az alkotók alkotás közben szignifikánsan magasabb flow-t élnek át, mint a kontrollcsoport tagjai egyéb szabadidős tevékenység végzése közben ( $\mathrm{p}=0.0003085)$. Az alkotók $a$ kontrollcsoporthoz képest szignifikánsan magasabb flow-t élnek át egyedüllét során ( $\mathrm{p}=0.02068$ ), továbbá a háztartással és a barátokkal töltött időben, illetve kisebb flow-t a családdal való együttlét során, azonban ez utóbbiak nem szignifikáns eltérések. Mindemellett az alkotók a kontrollcsoporthoz képest szignifikánsan alacsonyabb antiflow-t élnek át egyedüllét során ( $\mathrm{p}=0.04254)$, továbbá az alkotó tevékenységgel, háztartással és a barátokkal töltött időben, illetve nagyobb antiflow-t a családdal való együttlét során, azonban ez utóbbiak szintén nem szignifikáns eltérések.

Szignifikáns különbség tapasztalható az alkotók különféle helyzetekben átélt flow- (khi$\mathrm{sq}=36.161, \mathrm{p}=2.681 \mathrm{e}-07)$ és antiflow-értékei (khi-sq=39.958, $\mathrm{p}=4.416 \mathrm{e}-08)$ közt. Az alkotók a legmagasabb flow-t alkotó tevékenység végzése során élik át, s ez szignifikánsan eltér az 
egyedül, családi vagy baráti körben töltött idő során átélt flow-hoz képest (egyedülléthez képest: $\mathrm{p}=0.0007134)$. A legalacsonyabb flow-t háztartási munkák végzése közben élik át (egyedülléthez képest: $\mathrm{p}=0.0004334)$. Az egyedül, családi vagy baráti körben töltött idő során átélt flow között nincs szignifikáns eltérés. Az alkotók a legalacsonyabb antiflow-t családi és baráti körben, valamint alkotó tevékenység végzése során élik át, s ezek szignifikánsan eltérnek az egyedül töltött idő során átélt antiflow-hoz képest (családhoz képest: p=0.002837). A legmagasabb antiflow-t háztartási munkák végzése közben élik át (egyedülléthez képest: $\mathrm{p}=0.011146)$.

Szignifikáns különbség tapasztalható a kontrollcsoport különféle helyzetekben átélt flow - (khi-sq=36.905, p=1.885e-07) és antiflow-értékei (khi-sq=14.083, p=0.007034) közt is. A kontrollcsoport tagjai a legmagasabb flow-t családi körben élik át, s ez szignifikánsan eltér a baráti körben töltött idő vagy a szabadidős tevékenység végzése során átélt flow-hoz képest (szabadidős tevékenységhez képest: $\mathrm{p}=0.00176$ ). A legalacsonyabb flow-t háztartási munkák végzése és egyedüllét közben élik át (szabadidős tevékenység az egyedülléthez képest: $\mathrm{p}=0.0002816$ ). A baráti körben töltött idő és a szabadidős tevékenység végzése során átélt flow között nincs szignifikáns eltérés. A kontrollcsoport tagjai a legalacsonyabb antiflow-t családi körben élik át, s ez szignifikánsan eltér a szabadidős tevékenység és a háztartási munkák végzése, valamint a baráti körben töltött idő során átélt antiflow-hoz képest (családban: $\mathrm{p}=0.002837$ ). A legmagasabb antiflow-t egyedüllét során élik át (barátokhoz képest: $\mathrm{p}=0.01053$ ). A szabadidős tevékenység és a háztartási munkák végzése, valamint a baráti körben töltött idő során átélt antiflow között nincs szignifikáns eltérés.

A különböző helyzetekben átélt szorongás, unalom és apátia az alábbiak szerint alakult az alkotók csoportjában és a kontrollcsoportban: 


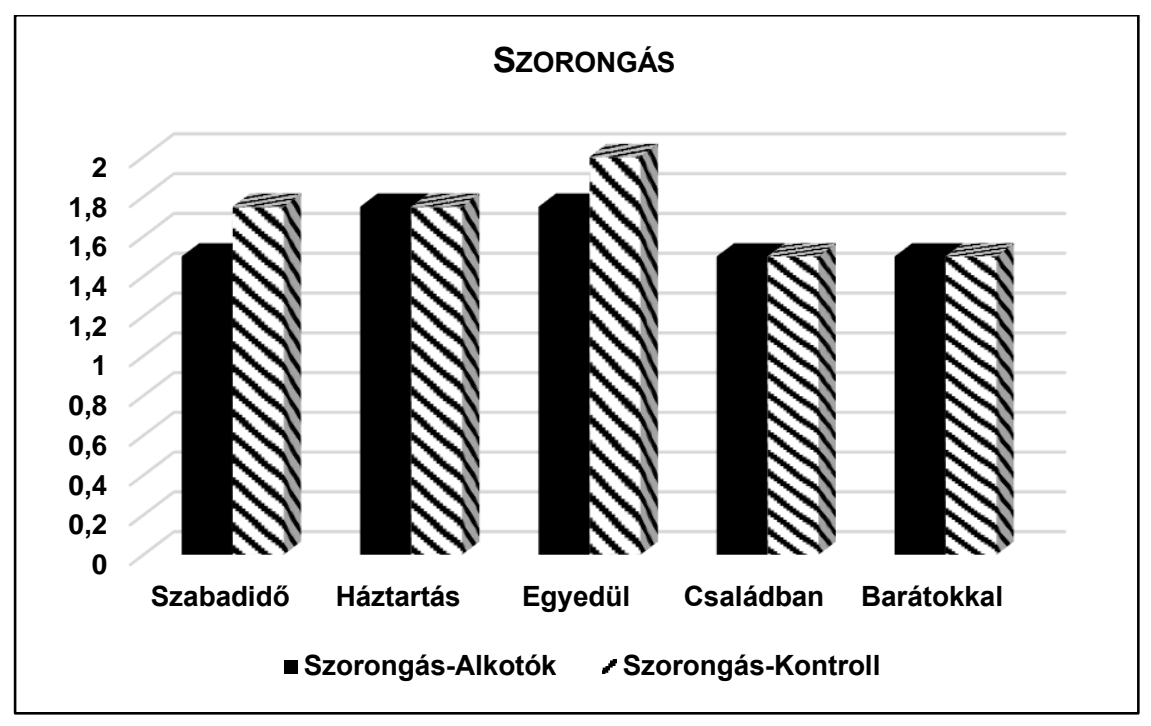

2. ábra: Különbözö helyzetekben átélt szorongás

Az alkotók a kontrollcsoporthoz képest szignifikánsan alacsonyabb szorongást élnek át alkotó tevékenység közben (kontrollcsoport szabadidős tevékenységéhez képest: $p=0.04093$ ), illetve szintén alacsonyabb (de nem szignifikáns) szorongást élnek át egyedüllét alatt. Egyéb helyzetekben a két csoport közt nincs szignifikáns különbség (2. ábra).

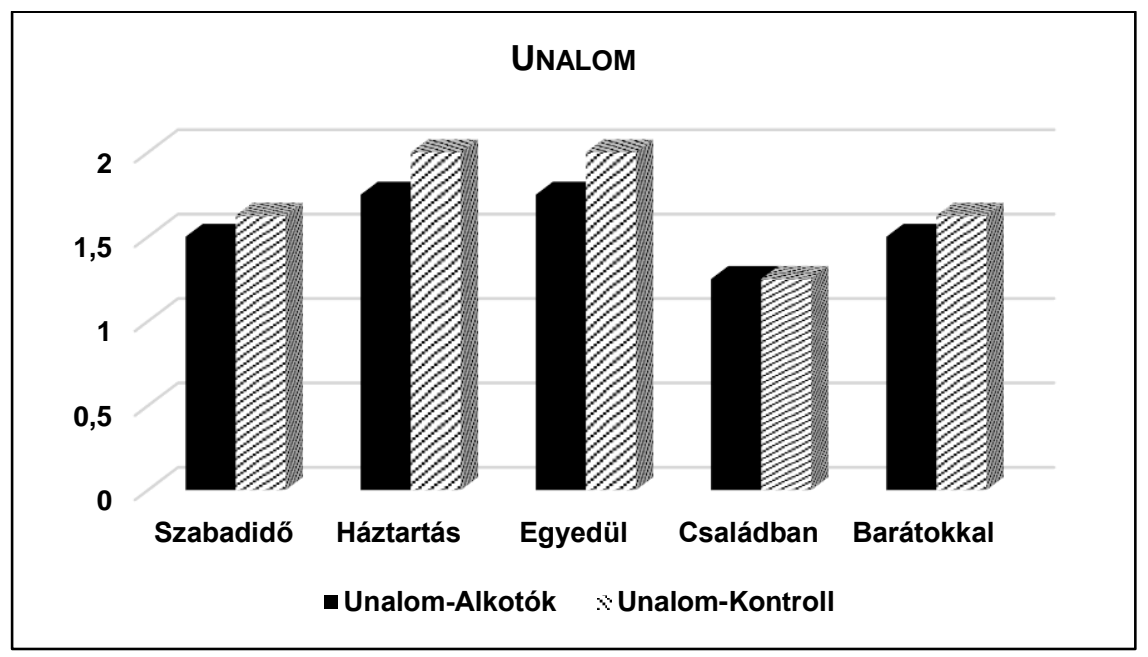

3. ábra: Különbözö helyzetekben átélt unalom

Az alkotók a kontrollcsoporthoz képest alacsonyabb (de nem szignifikáns) unalmat élnek át alkotó tevékenység és háztartási munkák végzése közben, továbbá a barátokkal és az egyedül töltött időben. A családi körben töltött idő alatt átélt unalom tekintetében a két csoport közt szintén nincs szignifikáns különbség (3. ábra). 


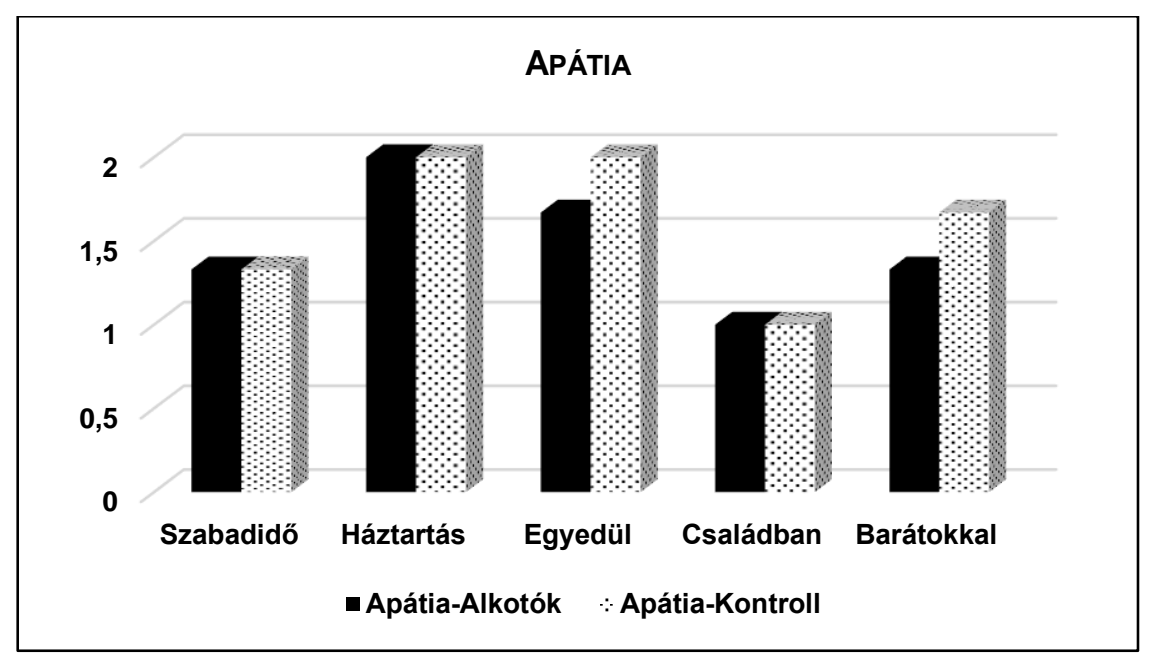

4. ábra: Különbözö helyzetekben átélt apátia

Az alkotók a kontrollcsoporthoz képest szignifikánsan alacsonyabb apátiát élnek át egyedüllét ( $\mathrm{p}=0.04562$ ), illetve szintén alacsonyabb (de nem szignifikáns) apátiát élnek át baráti társaságban. Egyéb helyzetekben a két csoport közt nincs szignifikáns különbség (4. ábra).

Az áramlat-élmény és az alkotó tevékenység idötartamának, továbbá rendszerességének kapcsolata

Az alkotó csoporton belül közepes erősségü, negatív irányú, szignifikáns $(\mathrm{p}<0.05)$ kapcsolat van a háztartási tevékenységek közben átélt antiflow (rho=-0.3339), s annak unalom (rho=-0.3507) és apátia (rho=-0.3191) összetevője, valamint az egyedül töltött idő során átélt szorongás (rho=-0.3726) és aközött, hogy a vizsgálati személyek milyen régóta végzik az alkotó tevékenységet (tevékenység végzésének időtartama).

Ugyancsak közepes erősségü, negatív irányú, szignifikáns $(\mathrm{p}<0.05)$ kapcsolat van a háztartási tevékenységek közben átélt antiflow (rho=-0.4319), s annak szorongás (rho=0.3586), unalom (rho=-0.3320) és apátia (rho=-0.5265) összetevője és aközött, hogy a vizsgálati személyek átlagosan heti hány órában végzik az alkotó tevékenységet (tevékenység végzésének gyakorisága). Szintén közepes erősségü, ugyanakkor pozitív irányú, szignifikáns kapcsolat van a háztartási tevékenységek közben átélt flow (rho=0.3502) és az alkotó tevékenység végzésének gyakorisága között.

Gyenge, negatív irányú kapcsolat van az egyedül töltött idő közben átélt antiflow (rho=0.1797), s annak szorongás (rho=-0.2471), unalom ( $\mathrm{rho=}=0.0650)$ és apátia (rho=-0.2198) összetevője és az alkotó tevékenység végzésének gyakorisága között. Gyenge, pozitív irányú 


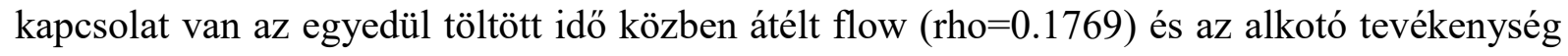
végzésének gyakorisága között. Ugyanakkor ezek nem szignifikáns kapcsolatok (p>0.1). Fentieken kívül az alkotó tevékenység időtartamának és gyakoriságának nincs szignifikáns hatása a többi változóra.

\section{KÖVETKEZTETÉSEK ÉS JAVASLATOK}

Kutatásunkban azt vizsgáltuk, hogy a maradandó alkotás létrehozására irányuló képzőművészeti, textilművészeti és kézműves alkotó tevékenységgel foglalkozó idősödő és időskorú emberek milyen áramlat-élményt, szorongást, unalom és apátia érzést élnek át különféle élethelyzetekben, például egyedüllét, családdal vagy barátokkal töltött idő, háztartási munkavégzés vagy szabadidős tevékenység, illetve alkotó tevékenység közben az alkotó tevékenységgel nem foglalkozókkal szemben.

Feltételezésünk szerint az alkotó tevékenység közben átélt áramlat-élmény áttevödik más tevékenységek végzésére, így a különféle élethelyzetekben mérhetöflow az alkotók esetében magasabb, mint a kontrollcsoportnál.

Feltételezésünket csak részben sikerült alátámasztani, mivel az alkotók a kontrollcsoporthoz képest csak alkotás és egyedüllét közben élnek át szignifikánsan magasabb flow-t, továbbá egyedüllét alatt élnek át szignifikánsan alacsonyabb antiflow-t. Ezen kívül az alkotók szignifikánsan alacsonyabb szorongást élnek át alkotó tevékenység közben, illetve szignifikánsan alacsonyabb apátiát élnek át egyedüllét alatt. Az egyedüllét csak a kontrollcsoport esetében bizonyult a legkevésbé kedvelt állapotnak, míg az alkotók csoportjában nem volt szignifikáns eltérés a baráti körhöz képest.

Feltételezésünk szerint az alkotó tevékenység időtartama (milyen régóta végzik a tevékenységet), illetve rendszeressége (heti hány órában végzik) hatással van az áramlatélményre.

Feltételezésünket csak részben sikerült alátámasztani. Minél régebb óta foglalkozik valaki alkotó tevékenységgel, annál kisebb antiflow-t, unalmat és apátiát él át háztartási tevékenységek végzése közben, illetve annál kisebb szorongást él át egyedüllét során. Minél több időt tölt valaki alkotó tevékenységgel heti szinten annál nagyobb flow-t, valamint annál kisebb antiflow-t, unalmat és apátiát él át háztartási tevékenységek végzése közben. 
Alkotó tevékenység és szabadidős tevékenységek végzése során tehát nagyobb flow és kisebb antiflow élhető át, mint háztartási munkák végzése közben mindkét csoport esetében, mely egybecseng a szakirodalmi adatokkal (Csíkszentmihályi, 1998; Bagdy és mts., 2014).

Csíkszentmihályi (1998) és Oláh (2005) szerint a baráti társaságban átélt flow magasabb, mint a családi körben átélt, míg a legalacsonyabb flow egyedüllét esetén mérhető. Jelen vizsgálatban azonban ezt nem sikerült igazolni, hiszen mind az alkotók csoportjában, mind pedig a kontrollcsoportban a családi körben átélt flow magasabb, mint a barátokkal töltött időben, amely annak is köszönhető, hogy az idősödés során a barátokkal szemben egyre inkább felértékelödik a család szerepe, a családi integritás, a kölcsönös segítségnyújtás, a család adta biztonságérzet. Ezen kívül az egyedüllét is csak a kontrollcsoport esetében a legkevésbé kedvelt állapot, míg az alkotók csoportjában nem volt szignifikáns eltérés a baráti körhöz képest.

Az alkotó tevékenység tehát segithet az egyedüllét során fellépő szorongás, továbbá a háztartási munkák - mint a vizsgálatban legkevésbé kedvelt tevékenység - végzése során elöforduló unalom és apátia leküzdésében. További kutatások során érdemes lenne megvizsgálni az alkotó tevékenységen kívüli egyéb, aktivitással vagy tanulással járó tevékenységek végzése közben átélt flow-élményt is időskorban.

\section{IRODALOMJEGYZÉK}

Bagdi E., Kövi Zs., Mirnics Zs. (2014): A tehetség kibontakozása. Helikon Kiadó, Budapest.

Brettner Zs., Mucsi G. (2013): A szociális munka szerepe az időskorúak fizikai, szellemi és szociálisaktivitásának megőrzésében, In: Kállai J., Kaszás B, Tiringer I. (szerk.): $A z$ időskorúak egészségpszichológiája. Medicina Kiadó, Budapest. 119-136.

Csíkszentmihályi M. (1997): Flow. Az áramlat. A tökéletes élmény pszichológiája. Akadémiai Kiadó, Budapest.

Csíkszentmihályi M. (1998): És addig éltek, amíg meg nem haltak. A mindennapok minősége. Kulturtrade Kiadó, Budapest.

Csíkszentmihályi M. (2008): A fejlödés útjai. A harmadik évezred pszichológiája. Nyitott Könyvmühely, Budapest.

Csíkszentmihályi M. (2010): Tehetséges gyerekek. Flow az iskolában. Nyitott Könyvmühely, Budapest.

Csíkszentmihályi M. (2014): Kreativitás. A flow és a felfedezés, avagy a találékonyság pszichológiája. Akadémiai Kiadó, Budapest. 
Delle Fave A. (2011): A szubjektív élmények hatása az életminőségre. In: Csíkszentmihályi M., Csikszentmihalyi I. S. (szerk.): Élni jó! Tanulmányok a pozitív pszichológiáról. Akadémiai Kiadó, Budapest. 215-235.

Frankl, V. E. (1996): Az ember az értelemre irányuló kérdéssel szemben. Kötet Kiadó, Budapest.

Halász L. (2006): Múvészetpszichológia. In: Bagdy E., Klein S. (szerk.): Alkalmazott pszichológia. Edge 2000 Kiadó, Budapest. 187-203.

Janurik M. (2007): Áramlatélmény az iskolai ének-zeneórákon. Magyar Pedagógia 107. évf. 4. szám 295-320.

Janurik M., Pethő V. (2009): Flow élmény az énekórán: a többségi és a Waldorf-iskolák összehasonlító elemzése. Magyar Pedagógia 109. évf. 3. szám 193-226.

Kerekes Zs. (2013): Idősödő személyiség és fejlődés. In: Kállai J., Kaszás B, Tiringer I. (szerk.): Az időskorúak egészségpszichológiája. Medicina Kiadó, Budapest. 105-118.

Oláh A. (2005.): Érzelmek, megküzdés és optimális élmény. Trefort Kiadó, Budapest

Pinczés T., Pikó B. (2014): Flow- és antiflow-élmények az Eysenck-féle személyiségdimenziók tükrében sportoló serdülök és kontrollcsoporto körében. Magyar Pedagógia 114. évf. 4. szám 221-236.

Reynolds F., Prior S. (2006): Creative Adventures and Flow in Art-Making: A Qualitative Study of Women Living with Cancer. British Journal of Occupational Therapy 69 (6) 255262 